\title{
AUTHOR'S CORRECTION
}

\section{Phylogenetic Interrelationships of Round-Spore-Forming Bacilli Containing Cell Walls Based on Lysine and the Non-Spore-Forming Genera Caryophanon, Exiguobacterium, Kurthia, and Planococcus \\ JOHN A. E. FARROW, SALLY WALLBANKS, AND MATTHEW D. COLLINS \\ AFRC Institute of Food Research, Reading Laboratory, Reading RG6 2EF, United Kingdom}

Volume 44, no. 1, p. 74-82. The description of Exiguobacterium acetylicum comb. nov. is identical to that provided for Brevibacterium acetylicum Breed 1957, 502 $\mathrm{AL}$ and set out in detail in Bergey's Manual of Systematic Bacteriology, vol. 2, p. 1309. 